\title{
ANALYSING THE DISMISSAL OF HIZBUT TAHRIR INDONESIA (HTI) IN THE CONTEXT OF FREEDOM OF ASSOCIATION
}

\author{
Bayu Marfiando \\ School of Global and Strategic Studies, Police Science Studies Program of Indonesia \\ University, Jakarta, bayumarfiando70@gmail.com
}

Citation: Bayu Marfiando, Analysing The Dismissal Of Hizbut Tahrir Indonesia (Hti) In The Context Of Freedom Of Association, Management Technology and Security International Journal, pages : 165-179, https://doi.org/10.47490/mtsij.v1.i2.165179

Received on 9 September 2020, Accepted on 23 October 2020, Published on 1 November 2020

\begin{abstract}
The dismissal of Hizbut Tahrir Indonesia (HTI) by the Indonesian government through a decree by the Jakarta Administrative Court Number 211/G/2017/PTUN.JKT - if it is related to freedom of association-is considered by some groups as a form of violation against citizens' rights which are protected by the 1945 Constitution. However, before dismissing HTI, the Indonesian government had carried out various and in-depth studies as well as taken considerations based on several views, such as (1) HTI had the potential to threaten the stability of the state, Indonesian democratic politics, and Indonesian political parties; (2) HTI had the potential to threaten the security stability by triggering rampant acts of terrorism and radicalism in Indonesia as well as demonstrations against policies issued by the government; and (3) HTI had the potential to threaten the existence of the integrity of the Republic of Indonesia by promoting the radical ideologies in which HTI has interest by replacing the state ideology with Islamic ideology in the form of khilafah Islamiyah or Islamic state.
\end{abstract}

Keywords: dissolution, freedom of association, Hizbut Tahrir Indonesia

\section{INTRODUCTION}

Humans are essentially social creatures because it is impossible for humans to live alone without interacting with other people (Soekanto, 1977:10). As social beings, humans will have desire to always have ties or to be united in an organization and association or better known as community or mass organization, either that is wellorganized or that is more open and loose. Each individual-through the bond in such organization - will be able to express himself and establish reciprocal relationships or jointly make efforts to carry out various activities and achieve the goals of the respective community/mass organization.

Post-reformation era and the global challenges experienced by the entire Indonesian people have created such rapid and dynamic changes. Most of Indonesian people are faced with conditions that are full of uncertainty and possibilities. This situation has come across with the strengthening of the process of democratization and openness as well as strengthening the local wisdom, the development of information and technology and a new lifestyle with a new value system that is completely based on freedom, high 
participation from community groups, both regarding human rights, forming associations of socio-political, economic and socio-cultural.

This phenomenon has caused the growth of community/mass organizations to find their best moment. Such situation and condition is like a fungus that grows in the rainy season. Many community/mass organizations have sprung up, with various backgrounds such as professional, ethnic (regional), youth, student, religious, and others. Mass organizations that take the name of nongovernmental organizations (NGOs) have also emerged from the central or national level to regional level. Such rapid development of the community/mass organizations are brought to light when their activities start disturbing social stability. Several facts have indicated the emergence of various mass organizations that carry out acts of anarchism, such as in Cikeusik, Pandeglang, Banten related to the Ahmadiyah congregation conflicts which has caused casualties and other acts of anarchism conducted by other organizations such as the Islamic Defenders Front (FPI) in the forms of carrying out the sweeping of liquor and entertainment places in various regions in Indonesia that have triggered pressures from various parties to immediately dismiss these community or mass organizations. (https://nasional.kompas.com/read/201 1/02/11/15583862/ FPI.Ancam.Gulingkan.SB).

The growth in the number of community/mass organizations and their types of activities in a democratic life increasingly demands the role, function and responsibility of those organizations to participate in the efforts to realize the Indonesian national ideals. However, in practice, there are some community/mass organizations that are considered to have desire to establish an Indonesian Islamic state and deny Pancasila as the ideology of the Indonesian nation. One of them is Hizbut Tahrir Indonesia (hereinafter HTI). In its operation, HTI has clearly stated that Pancasila is the ideology of Kufr (Al-Amin, 2012: 62). Whereas, Article 2 of Law Number 17/ 2013 concerning Community/Mass Organization emphasizes that "the principles of community/mass organizations should not contradict Pancasila and the 1945 Constitution of the Republic of Indonesia."

Ideologically, HTI is an Islamic political party organization that was founded in 1953 in the Middle East, precisely in Jordan. HTI has already established branches in nearly 30 countries including Indonesia. However, in Indonesia, HTI manifested as a community/mass organization that fights outside the country's political system to enforce Islamic law under the auspices of the daulah khilafah-a system of government led by a khalifah (https://www.kompasiana.com/alhakim/ 54ffa7bda33311ec4f5106ca/fenomenahti-kajian-akademis).

One of the reasons for establishing a khilafah state-according to HTI-is that current democratic political system is a representation of the ideologies of secularism and capitalism. They also 
view democracy not only as an ideology but as a means of colonization of western countries, especially the United States of America, to colonize countries with muslim populations. Thus, democracy must be rejected and replaced with Islamic ideology. In order to realize this ideology, HTI has pursued two strategies of resistance to the western world, namely: resistance to the thought and (2) political resistance.

As the name implies, Hizbut Tahrir means Liberation Party. On the official website of Hizbut Tahrir, it is stated that this organization is a political party, not a spiritual organization, not an educational institution, or not a social institution (which is engaged in social communities). If it is traced, HTI in the Ministry of Home Affairs had been registered as a social organization since 2000

(https://geotimes.co.id/kolom/hizbuttahrir-khilafah-dan-sikap-pemerintah).

Hizbut Tahrir Indonesia is known as a unique organization because it restored Islamic life by applying Islamic law as the rule of life. The attractiveness of HTI is different from the other organizations because it aggressively presents Islamic solutions in a coherent and systematic manner without further ado to address all kinds of problems of Muslims, especially living in Indonesia. All kinds of human problems are clearly explained and answered by HTI so that everyone can respond to the solutions of sharia and khilafah from the perspective of HTI, both from a scientific point of view and from a perspective of faith or belief. However, whatever the form and purpose that HTI carries, it is clear that this community/mass organization can threaten the current religious harmony in Indonesia. In several Middle Eastern countries, Hizbut Tahrir is included in the list of banned organizations.

Responding to this phenomenon, various pressures emerge from various parties that the government needed to immediately take firm legal actions and immediately dismiss the existence of HTI. In order to absorb the aspirations of the communities, finally the Indonesian government went through a long review process, through the Coordinating Minister for Political, Legal and Security Affairs. Wiranto officially announced that HTI was banned from operating in Indonesia on May 8, 2017. Wiranto also stated several reasons for dismantling HTI as follows:

a. Hizbut Tahrir Indonesia - as a legal entity_did not play a positive role in taking part in the development process in Indonesia in order to achieve the national goals;

b. Hizbut Tahrir Indonesia had carried out activities that were allegedly against the objectives, principles and characteristics of the state as written in Pancasila and 1945 Constitution of the Republic of Indonesia as regulated in Law Number 17/ 2013 concerning Community/Mass Organization; and

c. Hizbut Tahrir Indonesia had carried out activities that are considered to have caused clashes in society that could threaten security and public 
order and endanger the existence of the Republic of Indonesia. ${ }^{6}$

As a follow-up to the dismissal, the Indonesian Ministry of Law and Human Rights, through the Director General of General Legal Administration, then officially revoked the decree stating that HTI was a legal entity starting July 19 , 2017. Previously, HTI was registered at the Indonesian Ministry of Law and Human Rights as a legal entity. Its registration number, AHU00282.60.10.2014, was issued on July 2, 2014. Hizbut Tahrir Indonesia applied for its legal entity electronically through the website of the ministry named http://www.ahu.go.id. The decision to revoke the decree of the ministry taken by the Indonesian Ministry of Law and Human Rights was based on Government Regulation in Lieu of Acts (Perppu) Number 2/2017 concerning Amendments to Law Number 17/2013 concerning Community/Mass Organization which was ratified on July 10, 2017.

Hizbut Tahrir Indonesia did not remain silent. It immediately responded to the government's decision. Hizbut Tahrir Indonesia, through its attorney, Yusril Ihza Mahendra, on July 18 2017, submitted a formal and material test against the Government Regulation in Lieu of Acts (Perppu) Number 2/2017 concerning Community Organization to the Indonesian Constitutional Court (MK). On October 13, 2017, HTI even sued the Minister of Law and Human Rights and the Director General of General Legal Administration to the State Administrative Court (PTUN). In its lawsuit, HTI requested that the
Decree Number AHU-30.A.01.08 of 2017 concerning the Revocation of Legal Status of these mass organizations be cancelled. However, in practice the legal efforts made by HTI also had a deadlock because both the formal and judicial trials that were carried out at the Constitutional Court and the lawsuit that were filed at the State Administrative Court were both rejected by the panel of judges.

In practice, the dismissal of this HTI mass organization is considered by various groups to have violated freedom of association as citizens. The right to freedom of association is a fundamental one. The right to freedom of association is explicitly guaranteed in the Constitution, namely Article 28 of the 1945 Constitution and Article 28E of the 1945 Constitution. Apart from the constitution, the essence of the right to freedom of association is also regulated in Article 24 of Law No. 39 of 1999 concerning Human Rights which states that:

a. Everyone has the right to assemble, hold assembly and associate, for peaceful purposes.

b. Every citizen or community group has the right to establish a political party, non-governmental organization or other organizations to participate in the running of government and state administration in line with the demands for protection, enforcement and advancement of human rights in accordance with the provisions of laws and regulations. 
Whereas in the Universal Declaration of Human Rights, the right to freedom of association is guaranteed in article 20 stating:

a. Everyone has the right to freedom of assembly and association without violence.

b. No one may be forced to enter an association.

In the international human rights law, the right to freedom of association falls into the intersection zone between civil and political rights. This right must not be intervened by either the state or other parties because of the importance of the right to freedom of association for the existence and functioning of democracy. It is the fact that individual political interests will be more able to be fought for through an association with other people either through political parties, professional groups, organizations or other unions in order to fight for their interests.

Freedom of association is not only the freedom to establish an organization/labour union, but more than that it guarantees the implementation and purpose of the implementation of freedom of association in accordance with the constitution (the 1945 Constitution of the Republic of Indonesia). However, the implementation of protection, advancement and fulfilment of human rights in Indonesia is still experiencing ups and downs. One of the influencing factors is the tug of war between citizens on the one hand, and the interests of the state (government) on the other hand, which greatly affects the fulfilment of human rights for citizens. Although human rights have become norms and standards in the constitution, national legislation and international law, their implementation has not fulfilled the principle of "Law as it is in the book."

Based on this statement, what will be a formulation of the problem in the discussion of this paper is: How is the juridical analysis of the dismissal of HTI conducted by the Government of Indonesia in relation to freedom of association?

\section{THEORETICAL FRAMEWORK}

The establishment of the mass organization Hizbut Tahrir Indonesia (HTI) can be said to be a form of social action carried out by a group of people. In connection with this statement, the theory that will be used in the discussion of this writing is the theory of social action according to Max Weber. According to Weber, social action is closely related to conscious consideration and choice that the action is expressed.

Furthermore, Weber stated that social action is an individual action as long as the action has subjective significance or meaning for themselves and is directed to the actions of others. The social action that Weber refers to can be in the form of actions that are clearly directed at other people. It can also be in the form of "thoughts" or subjective actions that may occur due to the positive influence of a particular situation. 
The essence of Weber's theory is that social action, whatever its form is, can only be understood according to subjective meaning and the associated motivational patterns, because all behaviour not necessarily can be understood as manifestations of rationality. To know the subjective meaning and motivation of individuals who act, what is needed is the ability to empathize with the roles of others.

The establishment of community/mass organizations after the reformation several years ago has spread rampantly, apart from being a social act as part of human rights in the life of the nation and state within the framework of the Unitary State of the Republic of Indonesia (NKRI). This was truly realized by the founders of the nation long before the Reformation of the Amendments to the 1945 Constitution (UUD 1945) which was contained in Article 28 of the 1945 Constitution. Article 28 clearly prioritizes problems in appreciating organizations carried out by every element of society. This commitment is still carried out by the government with conditions on the goal of the country which is committed that "NKRI harga mati". That is why the pros and cons regarding community/ mass organizations that are present in Indonesia must be addressed wisely in maintaining the integrity of the Republic of Indonesia. One of the absolute requirements of a mass organization that is allowed to exist and develop in Indonesia is that it does not conflict with Pancasila and the 1945 Constitution, including any mass organizations based on any religious ideology that remains a part of the attention of the state as long as it does not conflict with Pancasila.

The issue of HTI arouse after the decision of their dismissal was publicised. The government through the Coordinating Minister for Politics, Law and Security as well as a study by the President ordered a number of organizations that opposed to Pancasila, including HTI that was strongly indicated to be against Pancasila and the 1945 Constitution, needed to examine wisely and through a clear legal process so that people were increasingly aware of the consequences and commitments of community/mass organizations in the life of society, nation and state.

In Article 28 of the 1945 Constitution prior to the Amendment of the 1945 Constitution, it is stated that: "Freedom of association and assembly, expressing thoughts orally and in writing and so on is stipulated in the Law". This statement provides clear evidence that the state is very concerned about the organizational life of the society in Indonesia. Moreover, the formulation of sovereignty through the 2001 Annual Session of the People's Consultative Assembly (MPR) was successfully changed to "Sovereignty is in the hands of the people and carried out according to the 1945 Constitution", providing enormous space for Indonesian people to live in democracy. Sovereignty in democracy in all fields certainly has implications for the life of mass organizations that are increasingly developing in the Reformation era. 
According to Law No. 17 of 2013 concerning Community/Mass Organizations, hereinafter referred to as Ormas, are organizations that are established and formed by the community on a voluntary basis based on the same aspirations, desires, needs, interests, activities, and objectives to participate in development for the achievement of the objectives of the Unitary State of the Republic of Indonesia on the basis of Pancasila. This statement is of course clear in the concept that every Ormas must aim to participate in development in order to achieve the goals of the Unitary State of the Republic of Indonesia.

Democracy, as part of paradigm shift, commonalities and differences of aspirations from time to time and also cultural evolution, grows and develops, that can propose a threat to national unity which is the context of democracy itself. The growing democracy in Indonesia has resulted in the emergence of community/mass organizations born in the reform era, including HTI. However, because in carrying out their activities and actions, HTI is in fact contrary to the prevailing constitution in Indonesia, then on May 8 2017, through the Coordinating Minister for Political, Legal and Security Affairs, the organization was prohibited from being existent in Indonesia.

However, the dismissal of HTI by the government had to be carefully examined and proven by legal means whether the organization was dangerous for the integrity of the Republic of Indonesia. In other words, the dissolution carried out by the government to HTI had to be carried out according to the existing procedures in the regulation that have been confirmed in Law No. 17 of 2013 concerning Community/Mass Organization. The terms and conditions for the dismissal procedure are clearly stated in the articles on the sanctions of the revocation of Community/Mass Organizations.

Before carrying out the dismissal of a community/mass organization that is indicated to be in conflict with Pancasila and the 1945 Constitution, the government must first carry out persuasive efforts before imposing administrative sanctions. Persuasive efforts can be made by the government by means of social control that is carried out without violence such as in terms of inviting or advising or guiding community members to act in accordance with religious values and community norms, of course, in this case related to matters that are in accordance with Pancasila as nation's life ideology.

If persuasive steps are disregarded, then the government can impose administrative sanctions. According to article 60 of Law Number 17 concerning Community/Mass Organization (Ormas) states that administrative sanctions can be carried out by the central government and regional government in accordance with the scope of their duties and authorities to impose to community/mass organization (Ormas) that violates the provisions. The administrative sanctions can be carried out in advance with a written warning, termination of 
assistance and/or grants; temporary suspension of activities; and/or revocation of registered certificate or revocation of legal entity status.

The warning is carried out in three tiered stages and valid for a maximum of 30 (thirty) days. If before the end of the stipulated time period, the Ormas (Community/Mass Organization) that violates the existing rules has complied with them, then the central government or local government can withdraw the warning.

\section{DISCUSSION}

\subsection{The Government Regulation in} Lieu of Acts (Perppu) on the

\section{Dismissal of HTI}

The existence of Community/Mass Organizations in the life of the community and nation is a form of the state's commitment to realizing the freedom of association and assembly guaranteed in the constitution. The state hopes that community/mass organizations can participate in realizing the national goals and policies within the framework of the Unitary State of the Republic of Indonesia based on Pancasila and the 1945 Constitution. This is a form of embodiment of democratic values in a constitutional state.

Community/mass organizations can play a role as a liaison and counterweight to the people's power against the state, as well as contribute positively as partners for the government in carrying out national development and improving people's welfare. In the context of socio-political life, community/mass organizations also contribute to the stability of order and security, so that they can sustain national unity and entity.

Thus, the existence of community/mass organizations is very important in the implementation of democratic rule of law because it becomes a medium for aspirations and control of citizens as the owner of sovereignty over the government.

In this context, the government has recognized the role of community/mass organizations in the administration of a democratic state, but has also emphasized the importance of respecting human rights and freedoms of others in exercising the rights and freedom of association and assembly, even at certain times the government considers the need to take firm action against community/mass organizations that commit anarchist actions and disturb the safety and security of others. To that end, the government has issued several laws and regulations relating to community/mass organizations. One of them is the regulation in Law Number 17/2013 concerning Community/Mass Organizations which have reasons for their formation in response to the complexity and dynamics of community/mass organizations development, thus requiring a more comprehensive management and legal arrangement. 
During its development, the Government renewed this regulation by issuing Perpu Number 2/2017 concerning Amendments to Law Number 17/2013 concerning Community Organization. The reason for the formation of this regulation is the discovery of mass organizations that are factually proven to have principles and activities that are contrary to Pancasila and the 1945 Constitution.

This regulation in the Government Regulation in Lieu of Acts (Perppu) has caused polemics in the community, especially in regard to the authority to disband any legal organization which carried out directly by the government without going through a court mechanism. Objections were conveyed from community/mass organizations that are members of the Civil Society Coalition to criticize this Perppu by stating that the legal process of dismissal should be carried out from the start through a process by the judiciary. Several experts in Constitutional Law, one of them Yusril Ihza Mahendra, considered that the Perppu issued by the government is a degression from democracy because the government should not be able to simply dissolve community/mass organization without going through a court mechanism. Some of these views show the reality of the community's response to this legal issue.
One of the crucial norms that is debated in the Perppu is the authority to disband community/mass organization (Ormas) by the government as regulated in Article 62 paragraph (3) and Article 80 A. Article 62 paragraph (3) regulates that the minister who holds the government affairs in the field of law and human rights in accordance with his/her authority revokes a registered certificate or revokes the status of a legal entity."

Meanwhile, Article 80A regulates the revocation of the status of a community/mass organization (Ormas)'s legal entity as referred to in Article 61 paragraph (1) letter c and paragraph (3) letter $b$, the community/mass organization shall be declared dismissed based on this the Government Regulation in Lieu of Acts."

The norm that regulates the dissolution of community/mass organization by the government has actually been tested several times in the Constitutional Court (MK), which is the guardian of constitution, the interpreter of constitution, the guardian of democratization, and the protector of human rights. At least, the examination of these norms has been carried out seven times against the Government Regulation in Lieu of Acts (Perppu) Number 2/2017 concerning Amendments to Law Number 17/2013 concerning Community/Mass Organization. (Perppu Ormas). 
Most of the cases that tested the Government Regulation in Lieu of Acts (Perppu) and the Amendments to Law concerning Community/Mass Organization (Ormas) questioned the constitutionality of the norms for the dissolution of Community/Mass Organization (Ormas) by the government, especially the regulations in Article 62 paragraph (3) and Article 80A of the Perppu. This shows that the constitutional issue of the norms for the dismissal of community/mass organization (Ormas) by the government has a very significant impact and affects community, so that many Community/Mass Organizations (Ormas) with various backgrounds have filed judicial reviews of the constitutionality of laws to the Constitutional Court. The development of legal politics on the authority to dismiss community/ mass organization (Ormas) certainly has an impact on the enforcement of the regulations. In practice, the government used the regulations to dissolve Hizbut Tahrir Indonesia (HTI) on the grounds that its activities and actions were against Pancasila and the spirit of the Republic of Indonesia. On the basis of the dismissal, HTI then tried to test the revocation through court channel. However, in the trial, the Jakarta State Administrative Court (PTUN) decided that the Decree of the Ministry of Law and Human Rights was in accordance with the current rules. HTI then filed an appeal to the Jakarta State Administrative High Court (PT TUN), however, PT TUN also stated that HTI was evidently proven to develop doctrine or concept that was contrary to Pancasila and UD 1945. Even though it was legal in PTUN and PTTUN, the court rejected the request.

In addition, it is worth remembering that such dismissal action also occurred during the New Order era in 1985 , namely the dissolution of the Indonesian Islamic Student Organization (PII) because the government determined that PII refused to make Pancasila as their organizational principle as ordered by the old community/mass organization (Ormas) law, so that the New Order regime dissolved the organization and declared it banned. In this context, violations of Pancasila and the 1945 Constitution are certainly prohibited actions because they threaten the integrity of the state and nation. However, the government must also continue to exercise this authority in accordance with the corridor of constitutionality and the perspective of protecting human rights and the right to freedom of association.

\subsection{Analysis of PTUN Court Decision No. 211/G/2017/PTUN.JKT concerning the Dismissal of HTI Related to Freedom of Association}


Jakarta PTUN Court Decision No. 211/G/2017/PTUN JKT regarding the dismissal of HTI if it is related to freedom of association was a form of violation committed by the government against citizens who are protected in the 1945 Constitution. However, it should be remembered that although the formation of community/mass organization (Ormas) is guaranteed by the 1945 Constitution, it does not mean that they can act and do activities freely. In other words, the organization's activities and actions must always be bound by restrictions in order to respect the human rights and freedom of others in the context of orderly law and creating justice in the life of the nation and state.

The existence of community/mass organization (Ormas) can be limited considering implementation of the right to freedom of association, assembly and expressing opinions as stipulated in Article 28E paragraph (3) of the 1945 Constitution which is included in the category of human rights can also be limited. It is in contrast to the right to life, the right to not to be tortured, the right to freedom of thought and conscience, the right to practice religion, the right not to be enslaved, the right to be recognized as a person before the law, and the right not to be prosecuted on the basis of retroactive law according to Article 28I, paragraph (1) of the 1945 Constitution which are included in the category of non-derogable rights under any circumstances.

In order to balance the exercise of the rights to freedom of association, assembly and expression of opinions so that it is not easily eradicated arbitrarily, restrictions by the government, such as dismissal of community/mass organization, remain bound to certain criteria. The criteria referred to as stipulated in Article 28J paragraph (2) of the 1945 Constitution, namely the restrictions stipulated by law, are carried out with the sole purpose of guaranteeing the recognition and respect for the rights and freedoms of others and the fulfilment of fair demands in accordance with moral considerations, religious values, security, and public order in a democratic society.

Therefore, in connection with the dismissal of HTI, it can actually be done as long as it is carried out for reasons and through procedures as stipulated by Law No. 17 of 2013 concerning Community/Mass Organization (Ormas). Apart from that, such dismissal was intended to ensure security and public order in a democratic society.

In the case of the dismissal of HTI, basically there were several adequate ratio legis (legal reasons) for the government to impose sanctions for revocation of legal entity status or the dismissal of HTI based on the decision of the Jakarta State Administrative Court No. 
211/ G/2017/PTUN.JKT. This was because HTI was deemed to have violated the Community/Mass Organization (Ormas) Law, namely:

a. HTI violated the obligation in Article 21 letter b, namely community/mass organizations (Ormas) are obliged to maintain the unity of the nation and the integrity of the Unitary State of the Republic of Indonesia. HTI's activities in public that was indicated carrying the ideology of khilafah and trying to eliminate the Republic of Indonesia were clearly a violation of this obligation.

b. HTI violated the obligation in Article 21 letter $\mathrm{f}$ which states that community/mass organizations (Ormas) are obliged to participate in achieving state goals. Of course, this participation can be achieved if community/mass organizations (Ormas) believe in the nation state system chosen by the founders of the Republic of Indonesia since August 17, 1945. It is impossible for the organizations that do not believe in the Republic of Indonesia and intend to replace it with another system can carry out the obligation and participate in achieving the goals of the Republic of Indonesia.

c. HTI violated the prohibition in Article 59 paragraph (2) letter c, which regulates that community/mass organizations (Ormas) are prohibited from carrying out separatist activities that threaten the sovereignty of the Republic of Indonesia. The definition of separatists according to the Big Indonesian Dictionary (KBBI) is "a person or group of people who intend to separate himself or themselves from a union/group (nation) for support." The notion of separatism does not necessarily mean taking up arms to separate and form a new state. The form of public campaign to invite people (community) to replace the state system (NKRI) with another system, namely the khilafah is basically categorized as a separatist threat to the sovereignty of the Republic of Indonesia.

Meanwhile, regarding the use of the provision of Article 59 paragraph (4) which states that community/mass organizations (Ormas) are prohibited from adhering to, developing and spreading doctrines or concepts that are contrary to Pancasila, it is rather difficult to apply in the HTI case. This is because there is an explanation of Article 59 paragraph (4) which limits the meaning of doctrines or concepts that are contrary to Pancasila, which only include the doctrines of atheism and communism/MarxismLeninism. 
For violations of Article 21 and Article 59 of the community/mass organizations (Ormas) Law, in accordance with Article 60 paragraph (1) of the Ormas Law, the government is granted an authority to impose administrative sanctions. According to Article 61 of the law, the types of administrative sanctions as follows:

a. Written warning;

b. Termination of assistance and/or grants;

c. Temporary suspension of activities; and/or

d. Revocation of registered certificate or revocation of legal entity status.

It must be understood that from the technique of formulating statutory norms the phrase "and/ or" which is placed in the last part of the second detail in Article 61 is actually an alternative form of cumulative sanctions. The consequence of this type of sanction model is that the government can gradually use all stages of the sanction imposition (cumulative). However, in certain circumstances or considerations, it is possible to pass several stages and immediately choose one form of sanctions (alternative).

If the government chose the cumulative sanctions, then the sanctions for HTI began with the first, second, and third written warning sanctions. Later, if they did not comply with the written warnings, the government would continue to terminate assistance and/or grants; and/or temporary suspension of activities by first requesting legal considerations from the Supreme Court. Conversely, if for certain considerations, namely calculating the harmful impact to state sovereignty, an organization is not immediately dissolved, the government according to Article 61 may choose an alternative sanction, namely directly imposing the heaviest sanction, namely revoking the status of a community/mass organizations (Ormas) legal entity without going through the 3 (three) previous stages.

If the government then decided to impose the sanction for revocation of legal entity status, it would be carried out using the provision of Article 70 paragraph (1) of the community/mass organizations (Ormas) Law, namely by submitting the dismissal of HTI to the district court by the prosecutor office upon a written request from the Minister of Law and Human Rights, then through this judicial process, the defendant, in this case HTI, was given the right to defend themselves by providing testimony and evidence in court.

\section{CONCLUSIONS}

Many are skeptical to the government regarding the Government Regulation in Lieu of Acts (Perppu) No. 2 of 2017 that officially deactivated community/mass organization (Ormas) such as Hizbut Tahrir Indonesia (HTI). Such attitude coincides with the feeling 
of suspicion, especially from the opposition to the current government. They think that the issuance of the Government Regulation in Lieu of Acts (Perppu) has injured the democratic process by relating it to the basic elements of the Perppu, namely freedom of thought, association, and expression. Such accusation is serious, until it continues to court. From this statement, it can be concluded that although the dismissal of HTI by some groups has violated the freedom of association, the government had strong reasons that the decision to dissolve HTI had been carefully reviewed and considered with the argument that HTI had violated the law and only created unproductive debates in public. This last reason indicates efforts to stabilize the political climate in Indonesia.

\section{IMPLICATIONS}

Regarding the dismissal of HTI which was deemed incompatible with the Pancasila ideology and the 1945 Constitution, in the future the government is expected to be more selective in granting permits to the establishment of Islamic community/mass organizations, because it is feared that at the time of registration the organizations do not conflict with Pancasila and the 1945 Constitution, but later in practice they do in contrary.

\section{REFERENCES:}

\section{A. BOOKS:}

Ainun Rafiq al-Amin, (2012), Dismantling the Khilafah Project a la Hizbut
Tahrir Indonesia, Yogyakarta: LKIS, 2012.

Ari Ganjar Herdiansah, "The Role of Community Organizations (Ormas) and Non-Governmental Organizations (NGOs) in Supporting Development in Indonesia", Journal of Socioglobal, Vol. 1 No. 1, December 2016.

Jimly Asshidiqie, (2010), Indonesian Constitution and Constitutionalism, Jakarta: Secretariat General and Registrar of the Constitutional Court.

Max Weber, (1964), The Theory of social and Economic Organization, edited by Talcot Parsons and translated by A.M. Handerson and Talcott Parsons, New York: Free Press.

Nowak, M. (2005), U.N. Covenant on Civil and Political Rights, CCPR Commentary, 2nd revised edition, N.P. Engel, Publishers.

Soerjono Soekanto, (1977), An Introduction to Sociology, Jakarta: University of Indonesia Publishers Foundation.

Wibowo, Catur and Herman Harefa, "The Urgency of Social Organization Inspection by the Government", Bina Praja Journal, Vol. 7 No. 1, 2015.

\section{B. LAWS and REGULATIONS:}

Law Number 17/ 2013 concerning Community Organization.

Government Regulation in Lieu of Law No. 2 of 2017 concerning Amendments to Law Number 17/ 2013 concerning Community Organization.

Decree of the Minister of Law and Human Rights No. AHU30.AHA.01.08.2017 concerning the Revocation of Decree of the Minister of Law and Human Rights No. 
AHU-00282.60.10.2014 concerning Ratification of the Establishment of the Indonesian Hizbut Tahrir Association.

\section{INTERNET/ WEBSITES:}

https://news.detik.com/berita/d-

571562/kontras-penerbitan-perppuormas-langkah-mundur, accessed on 10 June 2020.

https://www.merdeka.com/politik/yusriltentuk-pasal-karet-yang-berbahayadalam-perppuormas.html, accessed on 10 June 2020.

https://www.viva.co.id/berita/politik/9135

7-pancasila-dan-sejarahpembubaran-ormas-danpartaipolitik, accessed on 10 June 2020.

"Hizbut Tahrir, Khilafah, and the Government's Attitude", in https://geotimes.co.id/ column / hizbuttahrir-khilafah-and-attitude-government /, accessed on 20 June 2020.

"HTI Phenomena (Academic Studies)", accessed on 10 June 2020.

"This is the reason the government disbands Hizbut Tahrir Indonesia", in https: // national. kompas.com/read/2017/05/08/14382891/in i_alasan_pemerintah_bubarkan_hizbut_tah rir.indonesia, accessed on 10 June 2020.

"FPI Threatens to Overthrow SBY" in https://nasional.kompas.com/read/2011/ 02/11/15583862

FPI.Ancam.Gulingkan.SBY, accessed on 10 June 2020. 